\title{
Suitable Leadership Style for Service Industry in Bangkok
}

\author{
Sumas Wongsunopparat ${ }^{1}$ \\ $\mathrm{PhD}$, Johnson Graduate School of Management \\ Cornell University \\ United States of America \\ MBA, Tepper School of Business \\ Carnegie Mellon University \\ United States of America \\ Pranee Jaroensuk (Corresponding author) \\ Master of Business Administration \\ Bangkok University \\ Bangkok, Thailand
}

Received: January 1, 2021 Accepted: February 14, $2021 \quad$ Published: February 22, 2021

doi:10.5296/ijld.v11i1.18144 URL: https://doi.org/10.5296/ijld.v11i1.18144

\begin{abstract}
The main research question for this study "which leadership style is the most suitable for hotel industry in Thailand". This study adopted a case study of Centara hotel \& Resorts hotel chain. Study was conducted using anonymous online questionnaire. The Structural Equation Modeling (SEM) was used to test structural relationship in the model between various variables in the study. The finding of this study suggested that there is a significant relationship between autocratic relationship, high turnover intention, and low job satisfaction. In addition, the study found significant correlation between transformational leadership and democratic leadership with high job satisfaction and low turnover intention. This finding suggested that autocratic relationship is an ineffective leadership style to govern hotel employees in Thailand. On the other hand, both transformational leadership and democratic leadership are both effective leadership style that can possibly enhance employee job
\end{abstract}


satisfaction and reduce turnover intention. With consideration to the various departments in the hotel, the study also found that front office or reception, as well as food and beverage service department have significant correlation with democratic leadership style. Other leadership styles, including Laissez faire leadership, autocratic leadership, charismatic leadership, and transactional leadership show no significant relationship with employee job satisfaction and turnover intention. Thus, the finding of this study identified effective leadership style for hotel industry as transformational leadership and democratic leadership. The finding obtained from this study is novice and contribute greatly toward existing body of research as none of the past study have been conducted to investigate effectiveness of various leadership style in the context of Thai ever before. Lastly, this research is also extremely useful for hotel strategic human capital management to be able come up with the winning HRM \& HRD strategy to get the right kind of leaders and potential successors in their organizations in a highly rivalry intensity of over-supply hotel industry.

Keywords: Hotel industry, leadership style, service industry, suitable leadership

\section{Introduction}

Due to intense competition in this industry, it is crucial that hoteliers enhance its competitive advantage and maintain its market share. Since hotel is in service industry, customer service is the key toward the success in this market. While customer service is valuable, hotel employees are exceptional assets as they are the one who deliver services to hotel guest. However, many hotels face difficulties in human resource management, particularly employee retention. Turnover is a major issue for hotel sector, which causes significant disruption upon their departures (Narkhede, 2014). Past study documented that the annual turnover rate of hotel manager is as high as $80 \%$ (Wood and McCauley, 1989). Scholars suggested that impacts of employee turnover for hotel business can be divided into direct expenditure and intangible cost (Narkhede, 2014). High turnover rate is undesirable due to the associated incurred cost. Hotel are required to invest additional fund toward recruitment for replacement, as well as training, which are often very costly (Williams and O-Acheampong, 2016). Costs can also incurred indirectly from reduced productivity due to unfamiliarity of workplace, and poor service quality as a consequence of insufficient manpower (Aksu, 2004). Hotel reputation can also be damaged from the compromised standard and low morale as a result of the constant departure of colleagues (Narkhede, 2014). One factor influences employee turnover is leadership (Govindaraju, 2018). Past research suggested that $75 \%$ of individuals leave their job because of their bosses, which indicates that leaders role and their leadership styles are essential in employee retention (Ngethe, 2012). Leadership is a determinant of employee retention because it influence the level of job satisfaction ( $\mathrm{Rad}$ and Yarmohammadian, 2006a). Due to the of employee turnover in hotel business and the significant of leadership in employee, the aim of the study is to investigate the suitable leadership style for service industry in Bangkok.

\subsection{Rationale and Significance of the Study}

There are multiple reasons for hotel operator to maintain and enhance its competitive advantage. First, the growing expansion of hotel sectors in Thailand results in highly 
competitive market, which means that hotels need to put in more effort in order to maintain its market share. In addition, Thailand has encountered oversupply situation as shown by the diminished average occupancy rate in the past i.e. between 2000 and 2014. This situation reflects that it is important for hotel to maintain its competitive advantage so that they can survive or minimally affected by oversupply situation. Moreover, additional supply and competitive also comes from the growing number of condominiums and apartment in which the owner offers daily rental, usually by Airbnb. For these reasons the industry is highly competitive, and it is challenging for all hotels even five stars hotel to maintain its market share and strive in this intense industry. One way to enhance competitive is through customer satisfaction, which highly depends on customer service. This fact means that employees, especially those in direct contact with the hotel guests are valuable assets of the company. For this reason, human resource management is particularly important for this industry. Despite the importance of employees in hospitality industry, the industry demonstrates high turnover rate due to various reasons including leadership style. That being said, very limited number of studies have been done to investigate effectiveness of leadership style in enhancing employee retention. None of the study have been done in the context of Thai. Preference of leadership style may be affected by cultural influence. Thus, conducting a study specifically in Thai context is essential in obtaining reliable data that can be applied in business world. In addition, limited number of studies have been done to specifically look at luxury hotel. Customers staying at luxury hotel are often more demanding as they expected more due to the tremendous amount of money they paid. The demandingness of the customer can be stressful to hotel employees at a point in time, which may adversely impact the turnover rate and increase their demand for appropriate leadership. For this reason, it is crucial to conduct a study concerning luxury hotel industry. The knowledge obtained from this study will be helpful for luxury hotel operators to better manage its human resources and enhance its competitive advantage.

\subsection{Research Questions and Objectives}

Research question: Which leadership style is the most suitable for hotel industry?

- Research objective 1: To determine the most effective leadership style for hotel industry

- Research objective 2: To determine the most effective leadership style in retaining hotel employees in Bangkok.

- Research objective 3: To determine the most effective leadership style in enhancing employees' satisfaction

\subsection{Scope of the Study}

This study focuses majorly on luxury hotel industry in Bangkok and metropolitan area.

\section{Literature Review}

Thailand is one of the nations with the most developed tourism markets in Asia. According to UNTWO, Thailand continues to risk in the rankings as the world's top tourism destinations. 


\section{Macrothink}

Thailand moved up the ranks to $3^{\text {rd }}$ place from $5^{\text {th }}$ place regarding tourism receipts in its second year of double-digit growth, which is equivalent to 50 billion USD in 2016 (Table 1). The country also climbed up to $9^{\text {th }}$ position in term of international tourist arrivals (33 million) (table2) (World Tourism Organization, 2017).

By 2020, the number of visitors in Thailand is expected to rise to more than 40 million where the majority of the visitors will continue to arrive from the Asia Pacific region and Europe. Bangkok, Thailand's capital city, is among the top 10 of the World's most attractive cities. Thus, tourism industry is one of the country's main economic sectors accounting for $6-7 \%$ of its GDP. Revenue in this industry reached 2.5 trillion THB or 71 billion USD in 2016 with 870 billion contributing from domestic market and 1.6 trillion from international markets. The average daily spending of tourists in Thailand is 5,100 THB per person in 2016 and the value is expected to grow (Netherlands Embassy in Bangkok, 2018).

Table 1. International tourism receipts

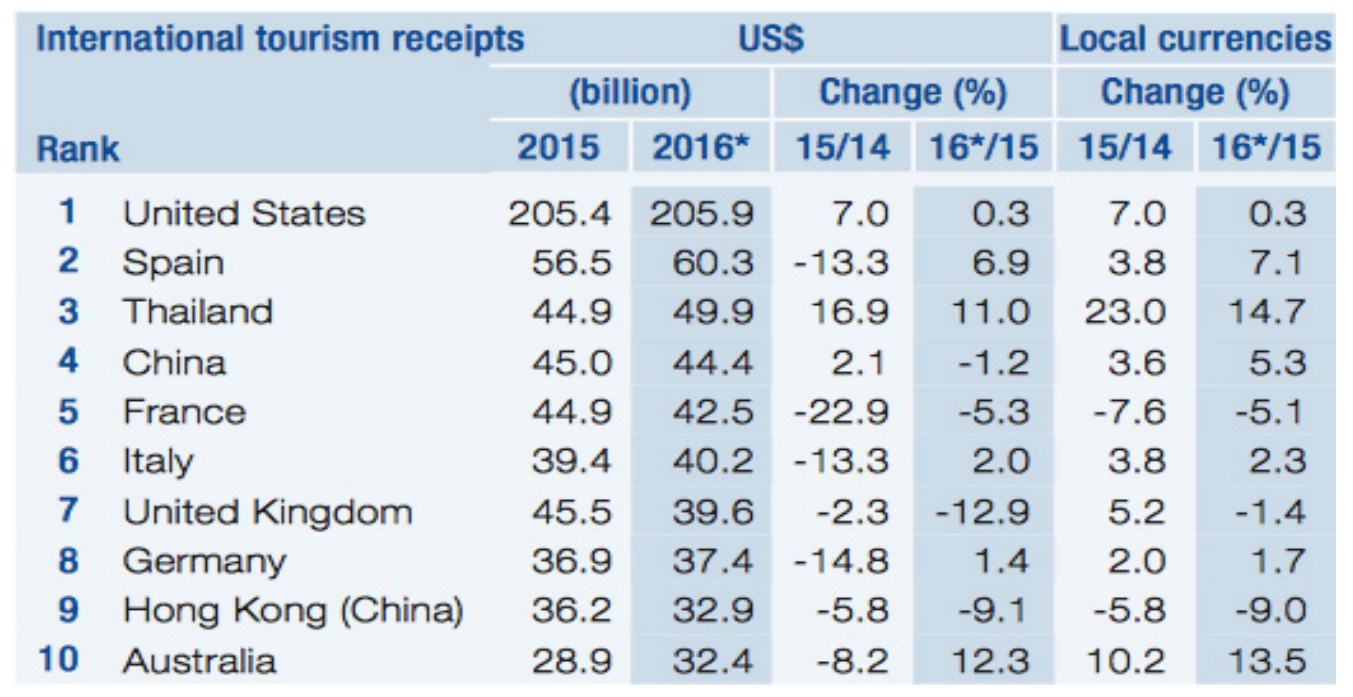

Source: UNWTO. 


\section{Macrothink}

Table 2. International tourist arrivals

\begin{tabular}{|c|c|c|c|c|c|c|}
\hline \multicolumn{7}{|c|}{ International tourist arrivals } \\
\hline \multirow{2}{*}{\multicolumn{2}{|c|}{ Rank }} & \multirow{3}{*}{$\begin{array}{c}\text { Series } \\
\text { TF }\end{array}$} & \multicolumn{2}{|c|}{ (million) } & \multicolumn{2}{|c|}{ Change (\%) } \\
\hline & & & 2015 & $2016^{\star}$ & $15 / 14$ & $16^{\star} / 15$ \\
\hline 1 & France & & 84.5 & 82.6 & 0.9 & -2.2 \\
\hline 2 & United States & TF & 77.5 & 75.6 & 3.3 & -2.4 \\
\hline 3 & Spain & TF & 68.5 & 75.6 & 5.5 & 10.3 \\
\hline 4 & China & TF & 56.9 & 59.3 & 2.3 & 4.2 \\
\hline 5 & Italy & TF & 50.7 & 52.4 & 4.4 & 3.2 \\
\hline 6 & United Kingdom & TF & 34.4 & 35.8 & 5.6 & 4.0 \\
\hline 7 & Germany & TCE & 35.0 & 35.6 & 6.0 & 1.7 \\
\hline 8 & Mexico & $\mathrm{TF}$ & 32.1 & 35.0 & 9.4 & 8.9 \\
\hline 9 & Thailand & TF & 29.9 & 32.6 & 20.6 & 8.9 \\
\hline 10 & Turkey & TF & 39.5 & .. & -0.8 &.. \\
\hline
\end{tabular}

Source: UNWTO.

Hotel industry in Thailand is growing. Figure 1 shows that RevPAR performance of Thailand continue to grow from 2014 to 2016 despite the decline in 2013. The average occupancy rate between 2000 and 2014 was 59\%. The cause of oversupply is responsible by increasing number hotel and accommodation investors in fast-growing tourism of Thailand. Moreover, apartments and condominiums owners are offering daily rental of their properties despite being considered as an illegal action.

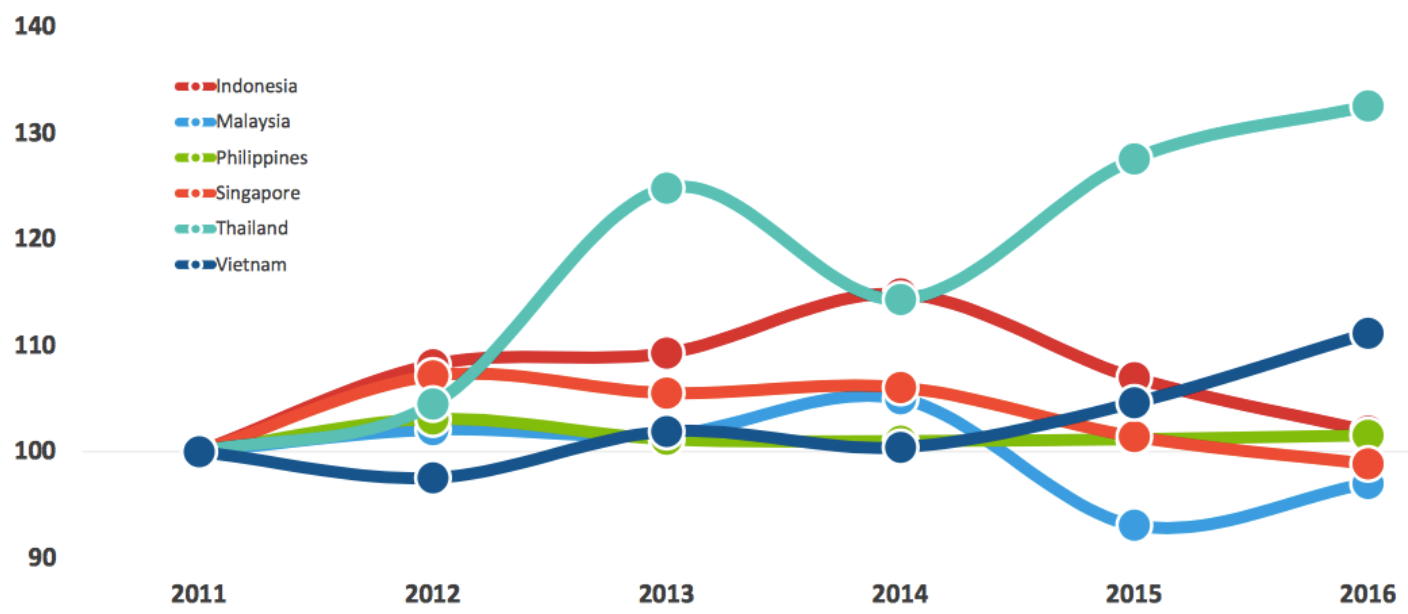

Figure 1. Countries RevPAR Performance (local currency) 


\subsection{Leadership Style}

Leadership style is the most important item of leadership process (Wood, 1993). Researcher suggested that leadership styles are important tools to create motivated employees which in turn help to achieve organisational goals (Kavanaugh and Ninemeier, 2001). Thus, hospitality organisations including hoteliers should employ effective leadership to improve guest services and employee job satisfaction (Woods and King, 2002). Since the early 1900s studies on leadership have established a large pool of theoretical materials relating to leadership concepts. Leadership style is defined as an interaction process among individual groups that includes a structured or restructured situation, members' expectations and perceptions (Bass, 1990). It is also defined as the pattern of behaviour that leaders act during work with and through others, as they perceive it (Hersey and Blanchard, 1993). In addition, other researcher proclaimed leadership style as the pattern of interaction between leaders and subordinates, which includes controlling, directing, techniques and methods that are used by leaders to motivate subordinates implementing the instructions (Miller et al., 2005).

\subsection{Leadership Style in Hotel Industry}

Characteristics of the hotel industry's work environment include long operating hours, a fast pace of activities, a labor-intensive diverse work force, growing competition, and dynamic travel patterns which can lead to high levels of stress for those managing in it. It is also very capital intensive with large amounts of money tied up in physical structures, furnishings and equipment. The lodging industry at its best can be difficult to manage. The capabilities required of a hotel general manager are demanding due to the unique characteristics of the industry. This is because hotels typically operate 24 hours per day, seven days a week, and 365 days a year; demand fluctuates significantly by season and/or economic factors; there are high labor costs; and unique management skills are required to motivate a highly diverse complement of staff and team members (Blayney and Blotnicky, 2010, Rutherford, 2002). Compared to managers in other industries, these job characteristics may exert increased daily management pressures on hotel managers (Rutherford, 2002). In the hospitality industry, the most common leadership style is the autocratic style because of unpredictable demands in the hospitality industry (Al-Ababneh, 2013a). The history of autocratic leadership style in hospitality industry creates some difficulties to adopt the participative leadership style, since there are deep roots of autocratic leadership style in hospitality industry (Wood, 1993).

\subsection{Leadership Style, Job Satisfaction and Turnover Intention}

A study investigating relationship between transformational leadership and job satisfaction among flight attendants confirmed that transactional leadership has a stronger influence on job satisfaction than transformational leadership does in an airline company (Tasi and Su, 2011). Similarly, another study indicated that the relationship between transformational leadership and job satisfaction is a positive significant relationship in national oil company (Shurbagi and Zahari, 2012). While study performed in Malaysia confirmed that two types of leadership styles, namely, transactional and transformational were found to have direct relationships with employees' job satisfaction (Voon et al., 2011), he results showed that transformational leadership style has a stronger relationship with job satisfaction in public 


\section{MInstitute ${ }^{\text {Mink }}$}

sector organizations. A study investigating the impact of autocratic and democratic leadership style on job satisfaction found that Leadership style has a positive impact on job satisfaction and public teachers have high level of job satisfaction rather than private teachers. The researcher concludes from the previous researches that leadership style has a relationship with employee's job satisfaction in different sectors (Bhatti et al., 2012).

\subsection{Conceptual Framework}

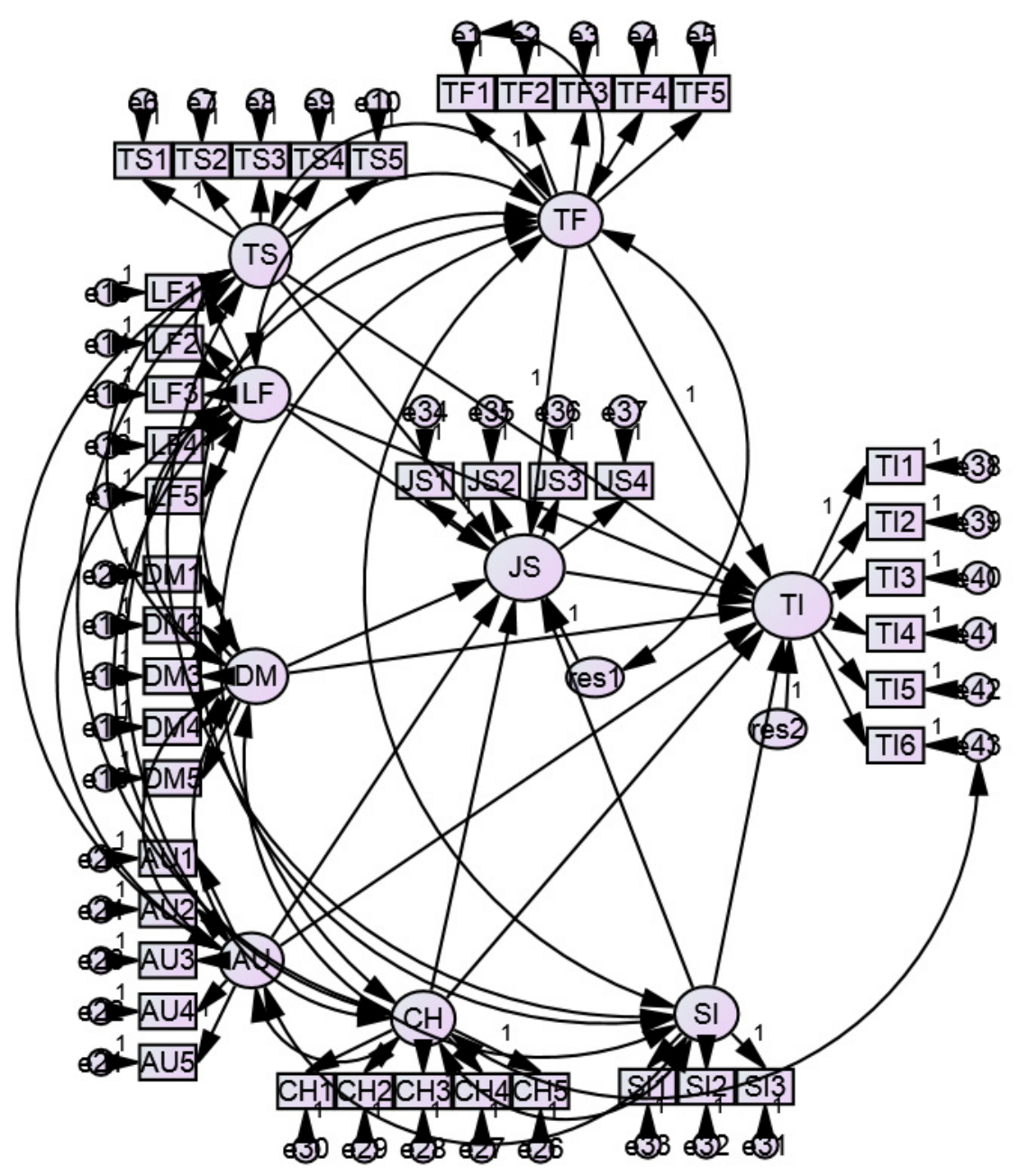

\section{Methodology}

The tool for methodology development used in this study was the "research onion", which was developed by Saunders, Lewise and Thornhill (2009). As shown in Figure 2, there are six layers to research onion including philosophy, approach to theory development, methodologic choice, research strategy, time horizon, and techniques and procedures Onion (Saunders \& Lewis, 2009). 


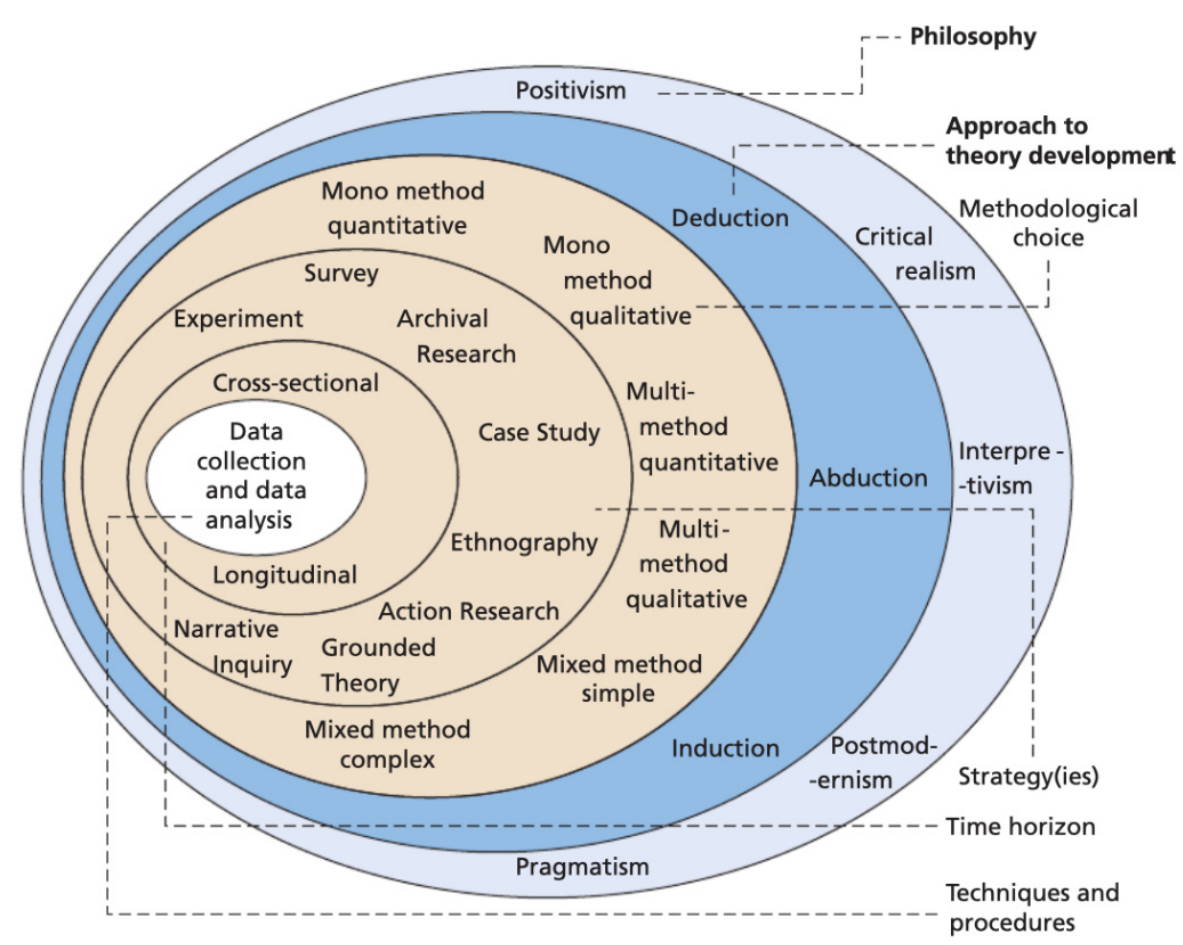

Figure 2. The Research Onion (Saunders \& Lewis, 2009)

\subsection{Techniques and Procedures}

\subsubsection{Sampling Design}

\subsubsection{Sampling Technique}

In term of sampling technique, there are two main sampling techniques, namely probability sampling and non-probability sampling (Saunders \& Lewis, 2009). The differences between the two sampling techniques are that probability sampling uses a random sampling technique to create a sample, while a non-probability sampling technique uses a non-random process (ibid, 2009). Due to a limited period of time, the non-probability sampling technique was more practical for this study. Firstly, this study relied on convenience sampling where the survey is given to close group of people that the researcher who that they are working in Centara hotels and resorts, based on convenience sampling, the researcher sent the link to the questionnaire to participants whom researcher has their contact detailed via e-mail, Line, or Facebook direct message. After convenience sampling, this study relied on snowball sampling, which is also referred to as chain-referral sampling, chain sampling, or referral sampling (Goodman, 1961). This technique allows researchers to acquire future participants from already recruited participants, i.e., the participants obtained through convenience sampling (ibid, 1961). This snowballing technique helped to acquire sufficient sample size in a shorter period of time. The researcher included a prompt at the end of the survey to encourage participants to share the questionnaire to people they know. The prompt also included the inclusion criteria, which are people who work in Centara hotel \& resorts. This 


\section{Macrothink}

information serves to ensure that the participant will be referring the survey to the right target population.

\subsubsection{Target Population}

Target population refers to the population of interest that meet the minimum requirement of the study (Brace, 2004). The identifying target population is important for the following step, which is sample size determination (ibid, 2004). The target population are employee of Centara Grand hotels and resort. There are around 1,000 employees working at Centara grand hotels and resorts (Owler, 2019).

\subsubsection{Sample Size}

Sufficient sample size is crucial for every research, especially those constructed based on positivism viewpoint (Cooper et al., 2003) as the sample size poses significant effect on the reliability of the results (Saunders, 2012). The estimated sample size of this study was done using Taro Yamane Formula at a 5\% sampling error and 95\% confidence level (Yamane, 1967). The calculation of sample size is detailed as followed.

$\mathrm{n}=\mathrm{N} /(1+\mathrm{Ne} 2)$

$\mathrm{n}=$ sample size

$\mathrm{N}=$ population size

$\mathrm{e}=$ precision level

Therefore, $\mathrm{n}=1,000 /[1+(1,000 * 0.05) 2]$

$\mathrm{n}=286$ samples

According to Yamane's formula for sample size calculation, the estimated sample size appropriate for this study is 286 samples. Thus, 286 questionnaires were distributed to employees of Centara Grand hotels and resorts.

\subsubsection{Questionnaire Design}

Preferential leadership style was assessed using the multi leadership questionnaire (MLQ). MLQ was chosen as a research instrument in this style because the purpose of using the MLQ which is to measure the perspectives of subordinates toward leadership style of the manager is similar to the objective of this study. While the initial MLQ concerns only two leadership styles namely transformational leadership and transactional leadership (Pimapunsri, 2014), this study assessed seven leadership styles including transformational leadership, transactional leadership, Laissez faire leadership, Situational leadership, Democratic leadership, Autocratic leadership, and charismatic leadership. Questionnaire of this study can be found in Appendix 1.

\subsubsection{Validity of the Questionnaire}

The questionnaire was presented to the supervisor for initial review. The questionnaire was then corrected and adjusted according to the comments and suggestions of the research 
supervisor. Once the edition and final approval from research supervisor have been obtained, the questionnaire was sent to three colleagues working in human resource management. The Item-Objective Congruence (IOC) was used to evaluate the items of the questionnaire based on the score range from -1 to +1 . The interpretation of the score range is as follow:

+1 indicates Congruent

0 indicates Questionable

-1 indicates Incongruent

The item had scored lower than 0.5 were revised. On the other hand, the items that had scores higher than or equal to 0.5 were considered as valid and were reserved (Rovinelli and Hambleton, 1977). The IOC value for each item was calculated using the summation of scores from each expert divided by the number of experts. The IOC value of every questionnaire item ranges from 0.66 to 1.0 (table 3 ). The values are all over than 0.5 indicating good content validity. The highest IOC of 1.0 was seen in most of the items while the lowest IOC (0.66) was observed in item TF5, DM5, and question 48.

Table 3. Results of questionnaire validity test using IOC

\begin{tabular}{|c|c|c|c|c|}
\hline & $\begin{array}{l}\text { IOC } 1 \\
\text { Expert } 1\end{array}$ & $\begin{array}{l}\text { IOC } \\
\text { Expert } 2\end{array}$ & $\begin{array}{l}\text { IOC } \\
\text { Expert } 3\end{array}$ & $\begin{array}{l}\text { Avg } \\
\text { IOC }\end{array}$ \\
\hline Question 6: TF1 & 1 & 0.5 & 1 & 0.83 \\
\hline Question 7: TF2 & 1 & 1 & 1 & 1 \\
\hline Question 8: TF3 & 1 & 1 & 1 & 1 \\
\hline Question 9: TF4 & 1 & 1 & 1 & 1 \\
\hline Question 10: TF5 & 0.5 & 1 & 0.5 & 0.66 \\
\hline Question 11: TS1 & 1 & 1 & 1 & 1 \\
\hline Question 12: TS2 & 0.5 & 1 & 1 & 0.83 \\
\hline Question 13: TS3 & 1 & 1 & 1 & 1 \\
\hline Question 14: TS4 & 1 & 1 & 1 & 1 \\
\hline Question 15: TS5 & 1 & 1 & 0.5 & 0.83 \\
\hline
\end{tabular}




\begin{tabular}{|c|c|c|c|c|}
\hline Question 16: LF1 & 1 & 1 & 1 & 1 \\
\hline Question 17: LF2 & 1 & 1 & 1 & 1 \\
\hline Question 18: LF3 & 1 & 1 & 1 & 1 \\
\hline Question 19: LF4 & 1 & 1 & 1 & 1 \\
\hline Question 20: LF5 & 1 & 1 & 1 & 1 \\
\hline Question 21: DM1 & 1 & 1 & 1 & 1 \\
\hline Question 22: DM2 & 1 & 1 & 0.5 & 0.83 \\
\hline Question 23: DM3 & 1 & 1 & 1 & 1 \\
\hline Question 24: DM4 & 1 & 0.5 & 1 & 0.83 \\
\hline Question 25: DM5 & 0.5 & 1 & 0.5 & 0.66 \\
\hline Question 26: AU1 & 1 & 1 & 1 & 1 \\
\hline Question 27: AU2 & 1 & 1 & 1 & 1 \\
\hline Question 28: AU3 & 1 & 1 & 1 & 1 \\
\hline Question 29: AU4 & 1 & 1 & 1 & 1 \\
\hline Question 30: AU5 & 1 & 1 & 1 & 1 \\
\hline Question 31: CH1 & 1 & 1 & 1 & 1 \\
\hline Question 32: CH2 & 1 & 1 & 1 & 1 \\
\hline Question 33: CH3 & 1 & 1 & 1 & 1 \\
\hline Question 34: CH4 & 1 & 1 & 1 & 1 \\
\hline Question 35: CH5 & 1 & 1 & 1 & 1 \\
\hline Question 36: SI1 & 1 & 1 & 1 & 1 \\
\hline
\end{tabular}




\begin{tabular}{|l|l|l|l|l|}
\hline Question 37: SI2 & 1 & 1 & 1 & 1 \\
\hline Question 38: SI3 & 1 & 1 & 1 & 1 \\
\hline Question 40 & 1 & 1 & 1 & 1 \\
\hline Question 41 & 1 & 1 & 0.5 & 0.83 \\
\hline Question 42 & 1 & 1 & 1 & 1 \\
\hline Question 43 & 1 & 1 & 1 & 1 \\
\hline Question 43 & 1 & 1 & 1 & 1 \\
\hline Question 45 & 1 & 1 & 1 & 1 \\
\hline Question 46 & 1 & 1 & 1 & 1 \\
\hline Question 47 & 0.5 & 1 & 1 & 0.83 \\
\hline Question 48 & 0.5 & 0.5 & 1 & 0.66 \\
\hline Question 49 & 1 & 1 & 1 & 1 \\
\hline
\end{tabular}

\subsubsection{Reliability Test}

The reliability of the questionnaire was determined so as to ensure that the responses collected through the instrument were reliable and consistent. Reliability also indicates the accuracy and precision of the measuring instrument i.e. questionnaire. Reliability test was done through a pilot study. The questionnaire was tested with 30 hotel staff that were not in the sample group. The internal reliability value was calculated by using Cronbach's alpha to ensure whether there was internal consistency within the items. The value of Coefficient Cronbach's Alpha is as followed:

$\geq 0.9=$ Excellent

$\geq 0.8=$ Good

$\geq 0.7=$ Acceptable

$\geq 0.6=$ Questionable

$\geq 0.5=$ Poor

$\leq 0.5=$ Unacceptable. 


\section{Macrothink}

Based on the information, the value of Coefficient Cronbach's Alpha must be at least 0.7 for research questionnaire to be reliable (Nunnally and Bernstein, 1994). To assess the reliability data were analyzed using Statistical Package for Social Sciences (SPSS). As shown in the table 4, the Cronbach's alpha of the questionnaire used in this study ranges between 0.713 and 0.959. The Cronbach's alpha as a result of the pilot test suggested demonstrated good reliability of the questionnaire.

Table 4. Results of reliability test

\begin{tabular}{|l|l|l|}
\hline Variables & Cronbach's Alpha & $\begin{array}{l}\text { Cronbach's Alpha based } \\
\text { on Standardized items }\end{array}$ \\
\hline Transactional leadership & 0.862 & 0.891 \\
\hline Transformational leadership & 0.713 & 0.806 \\
\hline Laissez faire leadership & 0.834 & 0.834 \\
\hline Situational leadership & 0.862 & 0.891 \\
\hline Democratic leadership & 0.959 & 0.958 \\
\hline Autocratic leadership & 0.869 & 0.879 \\
\hline Charismatic leadership & 0.870 & 0.885 \\
\hline Job satisfaction & 0.853 & 0.854 \\
\hline Employee turnover intention & 0.869 & 0.876 \\
\hline
\end{tabular}

\subsubsection{Data Analysis}

The numeric data obtained through quantitative research method was analyzed using the Statistical Package for Social Sciences (SPSS) programmed. The data was imported to SPSS programmed and encoded for analysis. This study relies on the SPSS programmed for three purposes, including reliability testing, and descriptive statistics. In addition, this study adopted Structural Equation Modeling (SEM) to use for Confirmatory Factor Analysis (CFA), which help confirm the theoretical relationship among and between various variables in the study. 


\section{Conclusion}

\subsection{Effective Leadership Style in Retaining Hotel Employees in Bangkok}

According to SEM analysis, leadership style that poses the most influence on turnover intention among hotel employees working in Bangkok was autocratic leadership. However, autocratic leadership has negative impacts on turnover intention. Autocratic leadership was found to be associated with high turnover intention. This finding corresponded with past study, which suggested that autocratic leadership generally has a negative reputation as the leadership style relies on centralization of power and decision making is usually more unilateral (Bass, 2008, Vugt et al., 2004). In addition, other study investigated the relationship of different leadership style on mobbing behaviors of superiors found among white-collar employees found that autocratic leadership increased the likelihood of mobbing behavior at workplace (Ertureten et al., 2013). Engaging in mobbing behaviors satisfies the authoritarian leader's need for control and power over the subordinates (Aryee et al., 2007). Moreover, autocratic leaders are usually unable to manage their emotions and for this reason they are more prone to display abusive behaviors at workplace (ibid, 2007). As a result, subordinates under autocratic leadership styles usually have higher turnover intention due to unfavorable working environment due to the autocratic leadership style.

This study also found significant correlations between transformational leadership and democratic leadership with low turnover intention. The major reason contributing to this finding is possibly due to the value of the employees perceived by the superior. Transformational leader usually concentrate on the growth and development of value system of employees, their inspirational level and moralities with the preamble of their abilities (Ismail et al., 2009). This means that subordinates are highly valued. Moreover, the leadership style considers individual needs of each subordinates and individual leader personality. In term of democratic leadership, subordinates opinions are high valued (Woods, 2004, Cassel, 1063). Other researchers have also found the positive influence of democratic leadership on turnover intention i.e. reducing turnover intention among employee (Martindale, 2011, Amanchukwa et al., 2015).

\subsection{Effective Leadership Style in Enhancing Employees' Satisfaction}

Job satisfaction among employees is highly associated with turnover intention in that employee with higher job satisfaction tend to display less turnover intention, and vice versa (Armstrong, 2003, Batura et al., 2016; Salman et al., 2016). Based on this suggestion, the study should obtain corresponding results between effective leadership style in reducing turnover intention and effective leadership style in enhancing employee satisfaction. Based on SEM analysis, the study found that transformational leadership was the leadership style that poses the most significant impacts on job satisfaction. This finding corresponded with other finding of this study that transformational leadership significantly reduces employee turnover intention. Transformational leadership is seen when leaders stimulate interest among their followers for new perspectives, develop them to reach higher levels of their potential, generate awareness among them for the mission and vision of the group, and motivate them to look beyond their own interests and consider the good of their group (Ismail et al., 2009; 
Bass \& Avolio, 1990) As such, transformational leaders transform their employees to reach higher performance standards and they initiate growth and change in the organization (Bass, 1990). Based on this emphasis of transformation leadership, employees have potential to grow and perform better. Thus, transformation leadership resulting in higher satisfaction (Bass, 1990).

\subsection{Limitation and Future Research Direction}

The limitation of this study is due to the research method. The study was conducted using an online questionnaire, which means that the sample size is limited by Internet penetration. Moreover, the study focuses only on hotel employees of Centara Grand Hotels and Resort, which means that the generalization of the result may not be valid. The study was also basing only on employees working in Bangkok and metropolis area meaning that the results may not be the same for employees working in other part of Thailand. Based on these limitations, future research should be done to ensure more generalization of the results, by involving hotel employees from other part of Thailand. This study also found significant influences of leadership styles on job satisfaction and turnover intention among hotel employees. Since ensuring job satisfaction and reducing turnover intention is essential in hotel industry with high turnover rate, future study could be done to account for other factors influencing job satisfaction and turnover intention. This way a human resource plan can be developed more comprehensively to reduce turnover intention and increase job satisfaction.

\subsection{Conclusion}

The aim of this study was to determine effective leadership styles that help enhance employee satisfaction and reduce employee turnover intention. Hotel industry is characterized by high turnover intention due to the demanding nature of the industry itself. Employees, however, are important assets to hotel industry as employees is key to exceptional customer service. Thus, maintaining low turnover intention and high employee satisfaction is highly essential. This finding suggested that authoritarian relationship is an ineffective leadership style to govern hotel employees in Thailand as the leadership style poses the most negative influences on turnover intention. On the other hand, both transformational leadership and democratic leadership are both effective leadership style that can possibly enhance employee job satisfaction and reduce turnover intention.

\section{Acknowledgement}

The research is part of independent study for Master of Business Administration. Thank you for Dr.Sumas Wongsunopparat, Bangkok University.

\section{References}

Ahmad, A., Salleh, A. M. M., Omar, K., Baker, K. A., \& Sha'sarani, K. A. W. (2018). The Impact of Leadership Styles and Stress on Employee Turnover Intention in Terengganu Hotel Community. International Journal of Enginerering \& Technology, 7, 38-42. https://doi.org/10.14419/ijet.v7i3.21.17091 
Aksu, A. A. (2004). Turnover costs: research among five star hotels in the city of Antalya, Turkey. Tourism Analysis, 9, 207-217. https://doi.org/10.3727/1083542042781230

Al-Ababneh, M. (2013a). Leadership Style of Managers in Five-Star Hotels and its Relationship with Employee's Job Satisfaction. IJMBS, 3, 93-98. https://doi.org/10.2139/ssrn.3633072

Al-Ababneh, M. (2013b). Leadership style of managers in five-star hotels and its relationship with employee's job satisfaction. International journal of Management \& Business Studies, 3, 93-98. https://doi.org/10.2139/ssrn.3633072

Amanchukwa, R. N., Nwachukwa, O. P., \& Stanley, G. J. (2015). A Review of Leadership Theories, Principles and Styles and Their Relevance to Educational Management. Management, 5, 6-14.

Armstrong, M. (2003). Handbook of Human Resource Management Practice. London, Kogan Page.

Aryee, S., Xiong, C. Z., Sun, L. Y., \& Debrah, Y. A. (2007). Antecedents and outcomes of abusive supervision: Test of a trickle-down model. Journal of Applied Psychology, 92, 191-201. https://doi.org/10.1037/0021-9010.92.1.191

Atieno, O. P. (2009). An analysis of the strengths and limitation of qualitative and quantitative research paradigms. Problems of education, 13, 13-18. https://doi.org/10.1111/j.1617-0830.2009.01127.x

Bass, B. M. (1990). Bass \& Stodill's Handbook of leadership: theory, research, and managerial applications. New York, The Free Press.

Bass, B. M. (2008). The Bass handbook of leadership: Theory, research, \& managerial applications. New York, Free Press.

Bass, B. M. \& Avolio, B. J. (1990). Developing transformational leadership: 1992 and beyond. Journal of European Industrial Training, 14, 21-27. https://doi.org/10.1108/03090599010135122

Bass, B. M. \& Avolio, B. J. (1993). Improving organizational effectiveness-Through transformational leadership. California, Sage Publications.

Bass, B. M., \& Avolio, B. J. (1994). Improving organizational effectiveness-Through transformational leadership. California, Sage Publications.

Batura, N., Skordis-Worral, J., Thapa, R., Basnyat, R., \& Morrison, J. (2016). Is the job satisfaction survey a good tool to measure job satisfaction amongst health workers in Nepal? Results of a validation analysis. BMC Med Res Methodol, 16, 1-13. https://doi.org/10.1186/s12913-016-1558-4

Bhatti, N., Maitlo, G. M., Shaikh, N., Hashmi, M. A., \& Shaikh, F. M. (2012). The impact of autocratic and democratic leadership style on job saitsfaction. International Business Research, 5, 192-201. https://doi.org/10.5539/ibr.v5n2p192 
Blayney, C. \& Blotnicky, K. (2010). Leadership in the hotel industry: evidence from Canada. International Journal of Management and marketing research, 3, 53-66.

Brace, I. (2004). Questionnaire design: how to plan, structure and write survey material for effective marketing research. London, Kogan Page.

Bryman, A., \& Bell, E. (2011). Business Research Method. New York, Oxford University Press.

Burns, J. M. (1978). Leadership. New York, Harper \& Row.

Burrel, G., \& Morgan, G. (2016). Sociological Paradigms and Organisational Analysis. Abingdon, Routledge.

Cassel, R. N. (1063). Democratic Leadership. The Educational Forum, 17, 437-441. https://doi.org/10.1080/00131725309341684

Chao, M. C., Jou, R. C., Liao, C. C., \& Kuo, C. W. (2015). Workplace stress, job satisfaction, job performance, and turnover intention of health care workers in rural Taiwan. Asia Pacific Journal of Public Health, 27, 1827-1836. https://doi.org/10.1177/1010539513506604

Chaudhry, A. Q., \& Javed, H. (2012). Impact of Transactional and Laissez Faire Leadership Style on Motivation. International Journal of Business and Social Science, 3.

Chen, J., \& Silverthrorne, C. (2005). Leadership effectiveness, leadership style and employee readiness. Leadership \& Organization Development Journal, 26, 280-288. https://doi.org/10.1108/01437730510600652

Conger, J. (2015). Charismatic Leadership. Organizational Behavior, 11. https://doi.org/10.1002/9781118785317.weom110122

Cooper, D. R., Schindler, P. S., \& Sun, J. (2003). Business research method, Boston, McGraw-Hill.

Crotty, M. (1998). The Foundations of Social Research. London, Sage.

Dbs Group Research. (2017). Thailand Industry Focus. Thailand Tourism Sector.

Eagly, A. J., Johannsen-Schmidt, M. C., \& Engen, M. L. V. (2003). Transformational, Transactional, and Laissez-Faire Leadership Styles: A Meta-Analysis Comparing Women and Men. Psychological Bulletin, 129, 569-591. https://doi.org/10.1037/0033-2909.129.4.569

Edet, A., Benson, U., \& Williams, R. (2017). Principals' conflict resolutoin strategies and teachers' job effectiveness in public secondary schools in Akwa Ibom State, Nigeria. Jouranl of Educational and Social Research, 7, 153-158. https://doi.org/10.5901/jesr.2017.v7n2p153

Erkutlu, H. V., \& Chafra, J. (2006). Relationship between leadership power bases and job stress of subordinates: example from boutique hotels. Management Research News, 29, 285-297. https://doi.org/10.1108/01409170610674419

Ertureten, A., Camalcilar, Z., \& Aycan, Z. 2013. The Relationship of Downward Mobbing 
with Leadership Style and Organizational Attitudes. Journal of Business Ethics, 116, 205-216. https://doi.org/10.1007/s10551-012-1468-2

Foels, R., Driskell, J. E., Mullen, B., \& Salas, E. (2000). The effects of democratic leadership on group member satisfaction: an integration. Small Group Research, 31, 676-701. https://doi.org/10.1177/104649640003100603

Glynn, M. A., \& Dejordy, R. (2010). Leadership through an organizational behavior lens: A look at the last half-century of research. Boston, Harvard Business Press.

Goodman, L. A. (1961). Snowballing sampling. Annals of Mathematical Statistics, 32, 148-170. https://doi.org/10.1214/aoms/1177705148

Govindaraju, N. (2018). Leadership Theories Influencing Employee Retention. International Journal of innovative Science and Research Technology, 3, 433-438.

Griffin, R. W. (2002). Management. New York, Joughton Mifflin Company.

Grint, K. (2011). A history of leadership. Thousand Oaks, Sage Publications.

Harrison, S., \& Gordon, P. A. (2014). Misconceptions of employee turnover: Evidence- based information for the retail grocery industry. Journal of Business \& Economics Research, 12, 145. https://doi.org/10.19030/jber.v12i2.8528

Hersey, P., \& Blanchard, K. H. (1993). Management of Organizational Behavior: Utilizing Human Resources. New Jersey, Prentice Hall Inc.

Hersy, P., \& Blanchard, K. H. (1969). Life cycle theory of leadership. Training \& Development, 23.

Hoogh, A. H. \& Hartog, D. N. (2009). Neuroticism and locus of control as moderators of the relationships of charismatic and autocratic leadership with burn-out. Journal of Applied Psychology, 94, 1058-1067. https://doi.org/10.1037/a0016253

Howell, J. M., \& Avolio, B. J. (1993). Transformational leadership, transactional leadership, locus of control and support for innovation: Key predictors of cons olidated -bus iness unit performance. Journal of service marketing, 16, 487-502.

Ismail, A., Halim, F. A., Munna, D. B., Abdullah, A., Shminan, A. S., \& Muda, A. L. (2009). The mediating effect of empowerment in the relationship between transformational leadership and service quality. Journal of Business Management, 4, 3-12. https://doi.org/10.5539/ijbm.v4n4p3

Johannesson, P., \& Perjons, E. (2014). Research Strategies and Methods. Sweden, Springer. https://doi.org/10.1007/978-3-319-10632-8_3

Johnson, P., \& Clark, M. (2006). Business and management research methodologies. London, SAGE publications. https://doi.org/10.4135/9781446260906

Jung, D. I. (2001). Transformational and transactional leadership and their effects on creativity in groups. Creativity Research Journal, 13, 185-195. 
https://doi.org/10.1207/S15326934CRJ1302_6

Kahai, S. S., Sosik, J. J., \& Avolio, B. J. (1997). Effects of Leadership Style and Problem Structure on Work Group Process and Outcomes in an Electronic Meeting System Environment. Personnel Psychology, 50. https://doi.org/10.1111/j.1744-6570.1997.tb00903.x

Kasikorn Research Center. (2018). Economic and Tourism Industry Outlook 2018. Bangkok: Kasikorn Research Center.

Kavanaugh, R. R., \& Ninemeier, J. D. (2001). Supervision in the Hospitality Industry, Michigan. The Educational Institute of the American Hotel \& Lodging Association.

Khalid, N., Pahi, M. H. \& Ahmed, U. (2016). Loosing Your Best Talent: Can Leadership Retain Employees? The Dilemma of the Banking Sector of Hyderabad Sindh, Pakistan: A Mediation Investigation. International Review of Management and Marketing, 6, 608-616.

Kim, S., \& Park, S. (2014). Determinants of job satisfaction and turnover intentions of public employees: Evidence from US federal agencies. International Review of Public Administration, 19, 63-90. https://doi.org/10.1080/12294659.2014.887354

Kovacs, G., \& M.Spens, K. (2005). Abductive reasoning in logistics research. International Journal of Physical Distribution \& Logistics Management, 35, 132-144. https://doi.org/10.1108/09600030510590318

Lahaney, B. A., \& Vinten, G. (1994). Methodology: An analysis of its meaning and use. Work study, 43, 5-8. https://doi.org/10.1108/00438029410058268

Locke, E. A. (1976). The nature and cause of job satisfaction, Chicago, Rand McNally.

Lok, P., \& Crawford, J. (2004). The effect of organizational culture and leadership style on job satisfaction and organizationl commitment. Journal of Management Development, 23, 321-338. https://doi.org/10.1108/02621710410529785

Long, C. S., Thean, L. Y., Ismail, W. K., \& Jusoh, A. (2012). Leadership styles and employees' turnover intention: exploratory study of academic staff in a Malaysian college. World Applied Science Journal, 19, 575-581.

Lorsch, J. W. (2010). A contingency theory of leadership. Boston, Harvard Business Press.

Lunkam, P. (2017a). Hotel Industry. Bangkok: Krungsri Bank.

Lunkam, P. (2017b). Thailand hotel industry outlook [Online]. Retrieved from https://www.krungsri.com/bank/getmedia/5de62d20-1706-48c1-9573-65359fdbc76c/IO_Hote 1_2017_EN.aspx [Accessed 20 May 2018].

Luthans, F. (2005). Organizational Behaviour, Irwin, McGraw Hill.

Martindale, M. (2011). Leadership styles: How to handle the different personas. Strategic Communication Management, 15, 32-35.

Melnikovas, A. (2018). Towards an Explicit Research Methodology: Adapting Research 
Onion Model for Futures Studies. Journal of Futures Studies, 23, 29-44.

Miller, J. E., Walker, J. R., \& Drummond, K. E. (2005). Supervision in the Hospitality Industry, New Jersey, John Wiley \& Sons Inc.

Narkhede, P. A. (2014). Employee turnover in hospitality industries a study of service staff. JIMS, 8, 4-8. https://doi.org/10.5958/0973-9343.2014.01230.7

Netherlands Embassy In Bangkok. (2018). Tourism industry in Thailand [Online]. Retrieved from https://www.rvo.nl/sites/default/files/2017/06/factsheet-toerisme-in-thailand.pdf

Neuman, L. W. (2002). Social research methods: Qualitative and quantitative approaches. United States of America, Pearson Education.

Ng'ete, J. M., Namusonge, G. S., \& Iravo, M. A. (2012). Influence of Leaership Style on Academic Staff Retention in Public Universities in Kenya. International Journal of Business and Social Science, 3, 297-302.

Ngethe, N. (2012). Influence of Leadership Style on Academic Staff Retention in Public Universities in Kenya. International Journal of Business and Social Science, 3.

Northhouse, P. G. (2004). Leadership: Theory and Practice. California, Sage Publications.

Nunnally, J. C., \& Bernstein, I. H. (1994). Psychometric theory. New York, McGraw-Hill.

Owler. (2019). Centara Hotels \& Resorts [Online]. Available: https://www.owler.com/company/centarahotelsresorts [Accessed 28 November 2019].

Pimapunsri, P. (2014). Learning organization and leadership style in Thailand. The business and management review, 4, 7-12.

Podsakoff, P. M., Mackenzie, S. B., Moorman, R. H., \& Fetter, R. (1990). Transformational leader behaviors and their effects on followers "trust in leader, satisfaction and organizational citizenship behaviors. Leadership Quaterly, 107-142.https://doi.org/10.1016/1048-9843(90)90009-7

Rad, A., \& Yarmohammadian, M. (2006a). A Study of Relationship between Managers' Leadership Style and Employees Job Satisfaction. Leadership in Health Services, 29, 11-27. https://doi.org/10.1108/13660750610665008

Rad, A. M. M., \& Yarmohammadian, M. H. (2006b). A study of relationship between managers' leadership style and employees' job satisfaction. Leadership in Health Services, 19, 11-28. https://doi.org/10.1108/13660750610665008

Rovinelli, R. J., \& Hambleton, R. K. (1977). On the use of content specialists in the assessment of criterion-referenced test item validity. Dutch J Educ Re, 2, 49-60.

Rutherford, D. (2002. Hotel management and operation. New York: John Wiley \& Sons.

Salman, M., Abdullah, F., \& Saleem, A. (2016). Sexual harassment at workplace and its impact on employee turnover intentions. Business \& Economic Review, 8, 87-102. 
https://doi.org/10.22547/BER/8.1.6

Sauer, S. J. (2011). Taking the reins: The effects of new leader status and leadership style on team performance. Journal of Applied Psychology, 96, 574-587. https://doi.org/10.1037/a0022741

Saunders, M. (2012). Reearch methods for business students. Harlow, Pearson Education.

Saunders, M. N. K., \& Lewis, P. (2009). Research methods for business student. Italy, Pearson Education.

Savery, L. K. (1994). The influence of the perceived styles of leadership on a group of workers on their attitudes to work. Leadership \& Organization Development Journal, 15, 4. https://doi.org/10.1108/01437739410059863

Scb Economic Intelligence Center. (2017). Insight: Three megatrends to change the face of the Thai tourism industry.

Scott, E. B. (2003). The role of transformational and transactional leadership in creating, sharing and exploiting organizational knowledge. Journal of leadership \& organization studies, 9, 32-44. https://doi.org/10.1177/107179190300900403

Seashore, S. E., \& Taber, T. D. (1975). Job satisfaction and their Correlations. American Behavioral Scientist, 18, 346-356. https://doi.org/10.1177/000276427501800303

Shamir, B., House, R. J., \& Arthur, M. B. (1993). The Motivational Effects of Charismatic Leadership: A Self-Concept Based Theory. Organization Science, 4, 577-594. https://doi.org/10.1287/orsc.4.4.577

Shin, J., Heath, R. L., \& Lee, J. (2011). A contingency explanation of public relations practitioner leadership styles: Situation and culture. Journal of Public Relations Research, 23, 167-190. https://doi.org/10.1080/1062726X.2010.505121

Shurbagi, A. M. A., \& Zahari, I. B. (2012). The Relationship between Transformational Leadership, Job Satisfaction and the Effect of Organizational Culture in National Oil Corporation of Libya. International Conference on Management, Applied and Social Sciences (ICMASS'2012). Dubai.

Specteor, P. E. (1985). Measurement of Human Service Staff Satisfaction: Development of the Job Satisfaction Survey. American Journal of Community Psychology, 13, 693-713. https://doi.org/10.1007/BF00929796

Spector, P. E. (2017). Job satisfaction: applications, assessment, causes, and consequences. California, Sage Publications Inc.

Srivatava, A., Bartol, K. M., \& Locke, E. A. (2006). Empowering leadership in management teams: Effects on knowledge sharing, efficacy, and performance. Academy of Management Journal, 49, 1239-1251. https://doi.org/10.5465/amj.2006.23478718

Tarigan, V., \& Wahyu, D. A. (2015). Empirical study relations job satisfaction, organizational 
commitment, and turnover intention. Advances in Management \& Applied Economics, 5, $21-42$.

Tasi, C. T., \& Su, C. S. (2011). Leadership, job satisfaction and service oriented organizational citizenship behaviours in flight attendents. African journal of business management, 5, 1915-1926.

Tobin, G. A., \& Begley, C. M. (2004). Methodological rigour within a qualitative framework. Journal of Advanced Nursing, 48, 388-396. https://doi.org/10.1111/j.1365-2648.2004.03207.x

Trottier, T., Van, W. M., \& Wang, X. (2008). Examining the Nature and Significance of Leadership in Government Organizations. Public Administration Review, 319-333. https://doi.org/10.1111/j.1540-6210.2007.00865.x

Uriarte, F. (2017). STR: Asia Pacific Hotel Update - Yesterday, Today \& Tomorrow [Online]. Retrieved $20 \quad$ May, 2018, from http://www.itb-asia.com/wp-content/uploads/2017/11/STR-ITB-Asia-2017Oct25.pdf

Voon, M. L., Lo, M. C., Ngui, N. S., \& Ayobe, N. B. (2011). The influence of leadership styles on employees' job satisfaction in public sector organizations in Malaysia. International Journal of Business, Management, and Social Sciences, 2, 24-32.

Vugt, M. V., Jepson, S. F., Hart, C. M., \& Cremer, D. D. (2004). Autocratic leadership in social dilemmas: A threat to group stability. Journal of Experimental Social Psychology, 40. https://doi.org/10.1016/S0022-1031(03)00061-1

Williams, A. A., \& O-Acheampong, E. (2016). Human resource management practices and their effect on employee turnover in the hotel industry in Cape coast, Ghana. Global Journal of Human Resource Management, 4, 35-45.

Woiceshyn, J., \& Daellenbach, U. (2018). Evaluating inductive vs deductive research in management studies: Implications for authors, editors, and reviewers. Qualitative Research in Organizations and Management: An International Journal, 13, 183-195. https://doi.org/10.1108/QROM-06-2017-1538

Wood, R. C. (1993). Organizational Behaviour for Hospitality Management, Oxford, Butterworth-Heinemann Ltd.

Wood, R. H., \& Mccauley, J. F. (1989). Rx for Turnover: Retention Programs that Work. Cornell Hotel and Restaurant Administration Quarterly, 30, 79-90. https://doi.org/10.1177/001088048903000119

Woods, P. A. (2004). Democratic Leadership: Drawing Distinctions with Distributed Leadership. International Journal of Leadership in Education. https://doi.org/10.1080/1360312032000154522

Woods, R. H., \& King, J. Z. (2002). Leadership and Management in the Hospitality Industry, Michigan. Education Institute of the American Hotel \& Lodgin Association.

WORLD TOURISM ORGANIZATION 2017. UNWTO Tourism Highlights 2017. 


\section{Macrothink \\ International Journal of Learning and Development \\ ISSN 2164-4063}

Wright, K. B. (2005). Journal of Computer-Mediated Communication. 10.

Yamak, O. U., \& Eyupoglu, S. Z. (2019). Leadership Styles of Hotel Managers in Northern Cyprus: Which Style is Dominant? International Journal of Organizational Leadership, 7, 1-11. https://doi.org/10.33844/ijol.2018.60202

Yamane, T. (1967). Statistics, New York, Harper and Row.

Yang, J. T. (2007). Knowledge sharing: Investigating appropriate leadership roles and collaborative culture $\quad$ Tourism Management, 28, 530-543. https://doi.org/10.1016/j.tourman.2006.08.006

Yoursef, D. A. (2000). Organizational Commitment: a mediator of the relationships of leadership behaviour with job satisfaction and performance in a non-Western Country. Journal of Managerial Psychology, 15, 6-24. https://doi.org/10.1108/02683940010305270

Yukl, G. (2008). Contingency theories of effective leadership. Thousand Oaks, Sage.

Yukl, G. (2010). Leadership in organizations. Englewood Cliffs, Prentice Hall.

Yukl, G. A. (1971). Toward a behavioural theory of leadership. Organizational Behavior and human performance, 6, 414-440. https://doi.org/10.1016/0030-5073(71)90026-2

Zalaghi, H., \& Khazaei, M. (2016). The role of deductive and inductive reasoning in accounting research and standard setting. Asian Journal of Finance \& Accounting, 8, 227-241. https://doi.org/10.5296/ajfa.v8i1.8148

\section{Copyright Disclaimer}

Copyright for this article is retained by the author(s), with first publication rights granted to the journal.

This is an open-access article distributed under the terms and conditions of the Creative Commons Attribution license (http://creativecommons.org/licenses/by/4.0/). 